\title{
Metode Demonstrasi Dalam Upaya Miningkatkan Proses Belajar Dan Hasil Belajar Bahasa Indonesia Sekolah Dasar Kelas V
}

\author{
Martha Mbindi \\ e-mail: marthambindi1962@gmail.com
}

\section{Guru Sekolah Dasar Inpres Wolowona 1, Ende, NTT}

\begin{abstract}
ABSTRAK: Berhasilnya tujuan pembelajaran ditentukan oleh banyak faktor diantaranya adalah faktor guru dalam melaksanakan proses belajar mengajar, karena guru secara langsung dapat mempengaruhi, membina dan meningkatkan kecerdasan serta keterampilan siswa. Untuk mengatasi permasalahan di atas dan guna mencapai tujuan pendidikan secara maksimal, peran guru sangat penting dan diharapkan guru memiliki cara/model mengajar yang baik dan mampu memilih model pembelajaran yang tepat dan sesuai dengan konsepkonsep mata pelajaran yang akan disampaikan. Permasalahan yang ingin dikaji dalam penelitian ini adalah: (a) Bagaimanakah peningkatan prestasi belajar siswa dengan diterapkannya metode pembelajaran demonstrasi? (b) Bagaimanakah pengaruh metode metode pembelajaran demonstrasi terhadap motivasi belajar siswa?
\end{abstract}

Kata kunci: metode demonstrasi, proses belajar, hasil belajar.

ABSTRACT: The success of learning objectives is determined by many factors including the factor of the teacher in implementing the teaching and learning process, because the teacher can directly influence, foster and improve student intelligence and skills. To overcome the above problems and to achieve educational goals to the fullest, the role of the teacher is very important and it is hoped that the teacher has a way / model of teaching that is good and able to choose the right learning model and in accordance with the concepts of the subject to be delivered. The problems that want to be studied in this study are: (a) How is the improvement of student learning achievement by applying the demonstration learning method? (b) What is the effect of demonstration learning methods on student motivation?

Keywords: demonstration methods, learnings outcomes, learning processes.

\section{PENDAHULUAN}

Pendidikan Bahasa Indonesia di sekolah dasar seharusnya membuahkan hasil belajar berupa perubahan pengetahuan, dan keterampilan yang sejalan dengan tujuan kelembagaan sekolah dasar. Sebagaimana dijelaskan dalam Kurikulum 1994, bahwa penyelenggaraan pendidikan di sekolah dasar bertujuan: (1) mendidik siswa agar menjadi manusia Indonesia seutuhnya berdasarkan Pancasila yang mampu membangun dirinya sendiri serta ikut bertanggung jawab terhadap pembangunan bangsa; (2) memberi bekal kemampuan yang diperlukan bagi siswa untuk melanjutkan pendidikan ketingkat yang lebih tinggi; dan (3) memberi bekal kemampuan dasar untuk hidup di masyarakat dan mengembangkan diri sesuai dengan bakat, minat, kemampuan dan lingkungannya (Depdikbud, 1994).

Dikaitkan dengan konteks pendidikan dasar sembilan tahun, maka fungsi dan tujuan pendidikan bahasa Indonesia di sekolah dasar harus pula mendukung pemilikan kompetensi tamatan sekolah dasar, yaitu pengetahuan, nilai, sikap, dan kemampuan melaksanakan tugas atau mempunyai kemampuan untuk mendekatkan dirinya dengan lingkungan alam, lingkungan sosial, lingkungan 
budaya, dan kebutuhan daerah. Sementara itu, kondisi pendidikan bahasa Indonesia di negara kita dewasa ini, lebih diwarnai oleh pendekatan yang menitikberatkan pada model belajar konvensional seperti ceramah sehingga kurang mampu merangsang siswa untuk terlibat aktif dalam proses belajar mengajar (Suwarma, 1991; Jarolimek, 1967). Suasana belajar seperti itu, semakin menjauhkan peran pendidikan bahasa Indonesia dalam upaya mempersiapkan warga negara yang baik dan memasyarakat (Djahiri, 1993)

Salah satu alternatif model pembelajaran yang dapat dikembangkan untuk memenuhi tuntutan tersebut adalah model metode pembelajaran demonstrasi. Yang dimaksud metode demonstrasi adalah salah satu cara mengajar, di mana guru melakukan suatu percobaan tentang sesuatu hal, mengamati prosesnya serta menuliskan hasil percobaannya, kemudian hasil pengamatan itu disampaikan ke kelas dan dievalusi oleh guru

\section{LANDASAN TEORI \\ Pengertian Pembelajaran}

Pembelajaran adalah proses, cara menjadikan orang atau makhluk hidup belajar. Sedangkan belajar adalah berusaha memperoleh kepandaian atau ilmu, berusaha tingkah laku atau tanggapan yang disebabkan oleh pengalaman (KBBI, 1996:14)

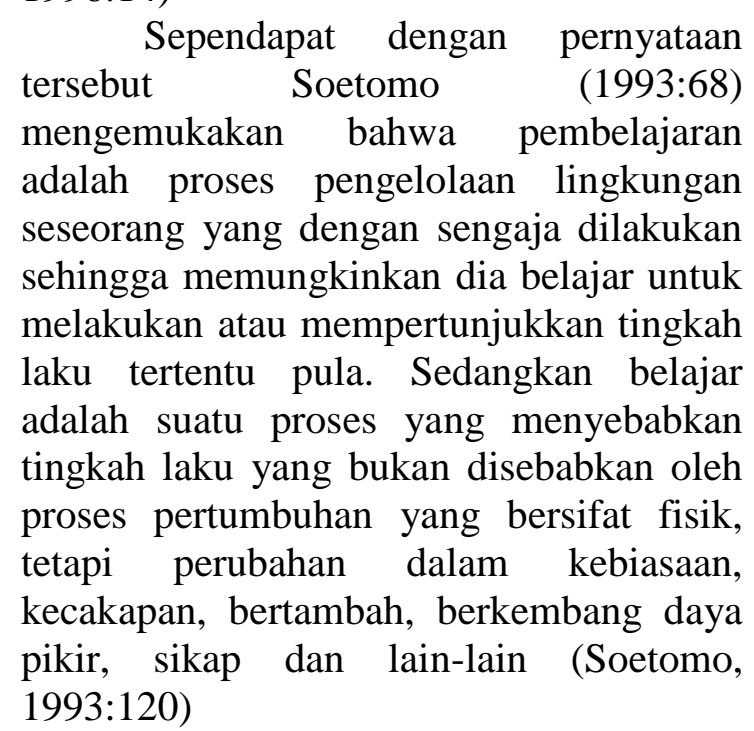

Pasal 1 Undang -undang No. 20 tahun 2003 tentang pendidikan nasional menyebutkan bahwa pembelajaran adalah proses interaksi peserta didik dengan pendidik dan sumber belajar pada suatu lingkungan belajar.

Jadi pembelajaran adalah proses yang disengaja yang menyebabkan siswa belajar pada suatu lingkungan belajar untuk melakukan kegiatan pada siatuasi tertentu.

\section{Pengertian Bahasa}

Dalam arti luas: Bahasa ialah alat yang dipakai manusia untuk memberi bentuk kepada sesuatu yang hidup di jiwanya, sehingga diketahui orang. Jadi disini termasuk juga mimiek (gerak muka), pantho mimiek (gerak anggota), dan menggambar.

Dalam arti umum : Bahasa ialah pernyataan perasaan jiwa dengan kata yang diisikan atau ditulis.

Apakah penguasaan bahasa? Mengerti apa yang dikatakan orang lain dan mempergunakan sendiri bahasa itu disebut menguasai bahasa. Orang yang telah menguasai sesuatu bahasa dengan baik dikatakan orang itu mempunyai penguasan bahasa yang baik.

\section{Macam - macam Penguasaan Bahasa}

Penguasaan bahasa itu ada dua macam, yaitu (1) penguasaan bahasa pasif : mengerti apa yang dikatakan orang lain kepadanya, dan (2) penguasaan bahasa aktif: dapat menyatakan isi hati sendiri kepada orang lain.

Dalam pengajaran bahasa di sekolah, penguasaan bahasa itu dapat dibagi menjadi dua yaitu: a)Penguasaan bahasa pasif yaitu mendengar dan membaca, b)Penguasaan bahasa aktif yaitu bercakap- cakap dan mengarang/menulis.

\section{Perbendaharaan Bahasa dan Tujuan Pengajaran Bahasa}

Tujuan terpenting ialah mebentuk pengertian; yang berarti: mengajarkan perkataan-perkataan baru dengan artinya sekaligus kepada anak - anak. Oleh karena 
itu, pada saat anak belajar membaca permulaan, jangan mulai dari menghafal huruf, tetapi mulai dari pola kalimat sederhana dan lembaga kata. Biasakan anak untuk mendengar, membaca, dan menuliskan yang mempunyai arti ganda.

Sekalian perkataan yang diketahui artinya oleh anak - anak dikatakan: perbendaharaan bahasa. Perbendaharan bahasa itu bertambah terus menerus pada anak-anak ataupun orang dewasa. Penambahan perbendaharaan bahasa ini telah dimulai sejak kelas I, pada saat anak telah dapat menuliskan apa yang telah didengarnya. Contoh: Mulai dari huruf a Abu, aku, anak, asik, aci, acar, api, dan seterusnya.

Dalam menambah perbendaharaan bahasa anak-anak ini, yang paling penting bukanlah isi dan arti, melainkan bentuk bahasa itu; meskipun sesungguhnya isi dan bentuk itu sukar diceraikan, karena bentuk itu menentukan isi. Jadi: Tujuan pengajaran bahasa ialah: a) Belajar memahami pikiran dan perasaan orang lain dengan teliti, jadi menangkap bahasa: mendengarkan dan membaca; b) Menyatakan pikiran dan perasaan sendiri dengan teliti, atau mempergunakan bahasa: berbicara/bercakap cakap dan menulis (dalam arti mengarang).

\section{Metode Demonstrasi}

Metode domonstrasi merupakan metode mengajar yang menyajikan bahan pelajaran dengan mempertunjukkan secara langsung objeknya atau caranya melakukan sesuatu untuk mempertunjukkan proses tertentu. Sebelumnya proses demonstrasi guru sudah mempersiapkan alat - alat yang digunakan dalam demonstrasi tersebut.

Prosedur metode demonstrasi yang harus dilakukan dalam pembelajaran adalah: 1) Mempersiapkan alat bantu yang akan digunakan dalam pembelajaran; 2) Memberikan penjelasan tentang topik yang akan didemonstrasikan; 3) Pelaksanaan demonstrsi bersamaan dengan perhatian dan peniruan dari siswa; 4)
Penguatan (diskusi, tanya jawab, dan atau latihan) terhadap hasil demonstrasi; dan 5) Kesimpulan.

Kemampuan guru yang perlu diperhatikan dalam menunjunjung keberhasilan demonstrasi : 1). Mampu secara proses tentang topik yang dipraktekkan; 2). Mampu mengelola kelas, menguasai siswa secara menyeluruh; 3). Mampu menggunakan alat bantu yang digunakan; 4). Mampu melaksanakan penilaian proses.

Kondisi dan kemampuan siswa yang harus diperhatikan untuk menunjang demonstrasi, diantaranya adalah: 1). Siswa memiliki motivasi, perhatian dan minat terhadap topik yang didemonstrasikan; 2). Memahami tentang tujuan yang akan didemonstrasikan; 3). Mampu mengamati proses yang dilakukan oleh guru; 4). Mampu mengidentifikasi kondisi dan alat yang digunakan dalam demonstrasi.

\section{PEMBAHASAN}

Hasil belajar siswa adalah nilai yang diperoleh siswa selama kegiatan belajar mengajar. Belajar diartikan sebagai gejala perubahan tingkah laku yang relatif permanen dari seseorang dalam mencapai tujuan tertentu De Cecco (dalam Witjaksono, 1985:6). Menurut Gagne (dalam Witjksono, 1985:6) belajar adalah suatu perubahan yang terjadi dalam disposisi atau kapabilitas seseorang, dalam kurun waktu tertentu, dan bukan sematamata sebagai proses pertumbuhan. Pendapat senada juga diutarakan oleh Susanto (1991:1) yang menyatakan bahwa belajar merupakan proses dimana otak atau pikiran mengadakan reaksi terhadap kondisi-kondisi luar dan reaksi itu dapat dimodifikasi dengan pengalamanpengalaman yang dialami sebelumnya. Melalui proses belajar anak dapat mengadaptasikan dirinya pada lingkungan hidupnya. Adaptasi itu dapat berupa perubahan pikiran, sikap, dan ketrampilan

Selaras dengan pernyataan di atas Bloom (dalam Budiningsih, 2005:75) menekankan perhatiaannya pada apa yang 
mesti dikuasai oleh individu. Tujuan belajar yang dikemukakannya dirangkum kedalam tiga kawasan yang terkenal dengan taksonomi Bloom adalah sebagai berikut:

1. Domain kognitiif, terdiri atas 6 tingkatan yaitu: a) Pengetahuan (mengingat, menghafal); b) Pemahaman (mengintepretasikan); c) Aplikasi (menggunakan konsep untuk memecahkan masalah); d)Analisis (menjabarkan suatu konsep; e) Sintesis (menggabungkan bagian-bagian konsep menjadi suatu konsep utuh);f) Evaluasi (membandingkan nilai-nilai, ide, metode, dsb).

2. Domain psikomotor, terdiri atas 5 tingkatan yaitu: a) Peniruan (menirukan gerak);b) Penggunaan (menggunakan konsep untuk melakukan gerak); c) Ketepatan (melakukan gerak dengan benar);d) Naturalisasi (melakukan gerak secara wajar).

3. Domain afektif, terdiri atas 5 tingkatan yaitu: a) Pengenalan (ingin menerima, sadar akan adanya sesuatu); b)Merespon (aktif berpartisipasi); c)Penghargaan (menerima nilai-nilai, setia kepada nilai-nilai tertentu);d) Pengorganisasian (menghubunghubungkan nilai-nilai yang dipercayainya); e) Pengalaman (menjadikan nilai-nilai sebagian bagian dari pola hidupnya).

Hasil belajar yang diukur pada pembelajaran yang berlandaskan kurikulum 2004 meliputi kemampuan kognitif, afektif, dan psikomotor. Maka guru tidak hanya menilai siswa dari aspek intelektual tetapi kemampuan sosial, sikap siswa selama proses belajar mengajar serta keaktifan siswa dalam kegiatan pembelajaran juga dinilai oleh guru

Benjamin S. Bloom dalam Taxonomy of Education Objectives (Winkel, 1996:274) membagi hasil belajar kedalam tiga ranah:
1. Ranah Kognitif

Ranah kognitif (berkaitan dengan daya piker, pengetahuan, dan penalaran) berorientasi pada kemampuan siswa dalam berfikir dan bernalar yang mencakup kemampuan siswa dalam mengingat sampai memecahkan masalah, yang menuntut siswa untuk menggabungkan konsepkonsep yang telah dipelajari sebelumnya. Ranah kognitif ini berkenaan dengan prestasi belajar dan dibedakan dalam enam tahapan, yaitu pengetahuan, pemahaman, penerapan, analsisi, sintesis, dan eveluasi. Pada siswa SMP diutamakan pada ranah pengetahuan, pemahaman, dan penerapan.

2. Ranah Psikomotor

Ranah psikomotor berorientasi kepada ketrampilan fisik, ketrampilan motorik, atau ketrampilan tangan yang berhubungan dengan anggota tubuh atau tindakan yang memerlukan koordinasi antara syaraf dan otot. Simpson (dalam Winkel, 1996:278) menyatakan bahwa ranah psikomotor terdiri dari tujuh jenis perilaku yaitu: persepsi, kesiapan, gerakan terbimbing, gerakan yang terbiasa, gerakan kompleks, penyesuaian pola gerakan, dan kreativitas.

Sedangkan menurut Kibler, Barker, dan Miles (dalam Dimyati dan Mudjiono,1994:195-196) ranah psikomotor mempunyai taksonomi berikut ini:

a. Gerakan tubuh yang mencolok, merupakan kemampuan gerakan tubuh yang menekankan kepada kekuatan, kecepatan, dan ketepatan tubuh yang mencolok.

b. Ketepatan gerakan dikordinasikan, merupakan 
ketrampilan yang berhubungan dengan gerakan mata, telinga, dan badan .

c. Perangkat komunikasi non verbal, merupakan kemampuan mengadakan komunikasi tanpa kata

d. Kemampuan berbicara, merupakan kemampuan yang berhubungan dengan komunikasi secara lisan. Untuk kemampuan berbicara, siswa harus mampu menunjukkan kemahirannya memilih dan menggunakan kata atau kalimat sehingga informasi, ide, atau yang dikomunikasikannya dapat diterima secara mudah oleh pendengarnya.

3. Ranah Afektif

Ranah afektif (berkaitan dengan perasaan/kesadaran, seperti perasaan senang atau tidak senang yang memotivasi seseorang untuk memilih apa yang disenangi) berorientasi pada kemampuan siswa dalam belajar menghayati nilai objek-objek yang dihadapi melalui perasaan, baik objek itu berupa orang, benda maupun peristiwa. Ciri lain terletak dalam belajar mengungkapkan perasaan dalam bentuk ekspresi yang wajar. Menurut Krochwall Bloom (dalam Winkel 1996:276) ranah afektif terdiri dari penerimaan, partisipasi, penilaian, dan penentuan sikap, organisasi, dan pembentukan pola hidup.Untuk ranah kognitif, guru menilai kemampuan kognitif siswa berdasarkan hasil tes yang diberikan kepada siswa pada akhir pelaksanaan siklus 1 dan 2 .

\section{KESIMPULAN}

Dari hasil kegiatan pembelajaran yang telah dilakukan selama tiga siklus, dan berdasarkan seluruh pembahasan serta analisis yang telah dilakukan dapat disimpulkan sebagai berikut:

1. Pembelajaran dengan demonstrasi memiliki dampak positif dalam meningkatkan prestasi belajar siswa yang ditandai dengan peningkatan ketuntasan belajar siswa dalam setiap siklus, yaitu siklus I $(68,18 \%)$, siklus II $(77,27 \%)$, siklus III $(86,36 \%)$.

2. Penerapan metode metode pembelajaran demonstrasi mempunyai pengaruh positif, yaitu dapat meningkatkan motivasi belajar siswa yang ditunjukan dengan hasil wawancara dengan sebagian siswa, rata-rata jawaban siswa menyatakan bahwa siswa tertarik dan berminat dengan metode metode pembelajaran demonstrasi sehingga mereka menjadi termotivasi untuk belajar.

\section{Daftar Pustaka}

Arikunto, Suharsimi. 1997. Dasar-dasar Evaluasi Pendidikan. Jakarta: Bumi Aksara.

Berg, Euwe Vd. (1991). Miskonsepsi bahasa Indonesia dan Remidi Salatiga: Universitas Kristen Satya Wacana.

Hamalik, Oemar. 2002. Psikologi Belajar dan Mengajar. Bandung: Sinar Baru Algesindo.

Joyce, Bruce dan Weil, Marsh. 1972. Models of Teaching Model. Boston: A Liyn dan Bacon.

Masriyah. 1999. Analisis Butir Tes. Surabaya: Universitas Press.

Mukhlis, Abdul. (Ed). 2000. Penelitian Tindakan Kelas. Makalah Panitia 
Pelatihan Penulisan Karya Ilmiah untuk Guru-guru se-Kabupaten Tuban.

Nur, Moh. 2001. Pemotivasian Siswa untuk Belajar. Surabaya. University Press. Universitas Negeri Surabaya.

Soedjadi, dkk. 2000. Pedoman Penulisan dan Ujian Skripsi. Surabaya; Unesa niversitas Press.

Suryosubroto, B. 1997. Proses Belajar Mengajar di Sekolah. Jakarta: PT. Rineksa Cipta.

Usman, Uzer. 2000. Menjadi Guru Profesional. Bandung: PT. Remaja Rosdakarya.

Widoko. 2002. Metode Pembelajaran Konsep. Surabaya: Universitas Negeri Surabaya. 